\title{
Circulating Exosomal CircMYC Is Associated with Recurrence and Bortezomib Resistance in Patients with Multiple Myeloma
}

\author{
Dolaşan Eksozomal CircMYC Multipl Myelomlu Hastalarda Nüks ve Bortezomib Direnciyle \\ Ilişkilidir
}

(D) Yanwei Luo, (D) Rong Gui*

The Third Xiangya Hospital of Central South University, Department of Blood Transfusion, Changsha, China

\section{Abstract}

Objective: Studies have shown that serum circRNA can be used as a biomarker for many tumors. However, the role of exosomal circRNA in prognostic evaluation in patients with multiple myeloma (MM) remains unclear. In this study, we aimed to analyze the role of circulating exosomal circMYC in the relapse and prognosis of patients with MM.

Materials and Methods: Circulating exosomes from 122 patients with $\mathrm{MM}$ and 54 healthy people were isolated. Quantitative polymerase chain reaction was performed to measure circMYC exosomal expression. Kaplan-Meier survival curves with log-rank testing were used for estimating significance in survival rates. A Cox regression model was used for univariate and multivariate analysis.

Results: Compared with healthy people, the expression level of serum exosomal circMYC was significantly increased in patients with MM. In addition, the expression of circMYC in circulating exosomes in bortezomib-resistant patients was significantly higher than that in non-resistant patients. The expression level of exosomal circMYC was correlated with deletion $17 \mathrm{p}, \mathrm{t}(4 ; 14)$, Durie-Salmon staging, and the International Staging System. Univariate and multivariate Cox regression analysis found that a high exosomal circMYC level was an independent predictor of poor prognosis in patients with MM. The patients with high exosome circMYC expression had higher relapse rates and higher mortality rates. The overall survival rate and progression-free survival rate of MM patients with high exosomal circMYC expression were lower than those of patients with low exosomal circMYC expression.

Conclusion: These findings suggest that circulating exosomal circMYC has great potential as a biomarker for the diagnosis and prognosis of MM.

Keywords: Circular RNA, Biomarker, Drug resistance, Overall survival, Hematological tumor

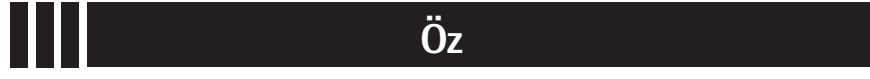

Amaç: Çalışmalar göstermiştir ki serum circRNA pekçok tümör için biyobelirteç olarak kullanılabilir. Ancak, multiple myelomlu (MM) hastalarda eksozomal circRNA'nın rolü belirsizdir. Bu çalışmada dolaşan eksozomal circMYC'nin MM'li hastaların nüks ve prognozundaki rolünü analiz etmeyi hedefledik.

Gereç ve Yöntemler: MM'li 122 hasta ve 54 sağlıklı kişiden dolaşan eksozomlar izole edildi. Kantitatif polimeraz reaksiyonu circMYC eksozomal ekspresyonunu ölçmek için uygulandı. Sağkalım oranının önemini tahmin etmek için log-rank testiyle beraber Kaplan-Meier sağkalım eğrileri kullanıldı. Tek değişkenli ve çok değişkenli analiz için Cox regresyon modeli kullanıldı.

Bulgular: Sağlıklı kişilerle karşılaştırıldığında MM'li hastalarda serum eksozomal circMYC ekspresyon düzeyleri anlamlı ölçüde artmıştı. İlaveten, dolaşan eksozomlarda circMYC ekspresyonu bortezomibe dirençli hastalarda dirençli olmayanlara göre anlamlı ölçüde yüksekti. Eksozomal circMYC ekspresyon düzeyi delesyon 17p, t(4;14), DurieSalmon evrelemesi ve Uluslararası Evreleme Sistemi ile bağlantılıydı. Tek değişkenli ve çok değişkenli Cox regresyon analizi yüksek eksozomal circMYC düzeyinin MM'li hastalarda kötü prognozun bağımsız göstergesi olduğunu gösterdi. Yüksek eksozom circMYC ekspresyonu olan hastalarda daha yüksek nüks ve mortalite oranı vardı. Yüksek eksozomal circMYC ekspresyonu olan MM'lu hastaların genel sağkalım ve ilerlemesiz sağkalım oranı düşük eksozomal circMYC ekspresyonu olan hastalardan daha düşüktü.

Sonuç: Bu bulgular dolaşan eksozomal circMYC'nin MM tanı ve prognozu için biyobelirteç olma potansiyeli olduğunu düşündürmektedir.

Anahtar Sözcükler: Sirküler RNA, Biyobelirteç, İlaç direnci, Genel sağkalım, Hematolojik tümör

๑Copyright 2020 by Turkish Society of Hematology

Turkish Journal of Hematology, Published by Galenos Publishing House 


\section{Introduction}

Multiple myeloma (MM) is the most common type of human plasma cell disease, accounting for about 10\% of all hematological tumors [1]. In patients with $\mathrm{MM}$, the malignant plasma cells in the bone marrow rapidly proliferate and secrete a large number of monoclonal immunoglobulins in different parts of the body, which causes a series of clinical manifestations such as renal insufficiency, bone destruction, anemia, and hypercalcemia [2]. Although in the past 10 years, with the continuous development of new drugs and the development of stem cell transplantation, the overall survival time and quality of life of patients with MM have been greatly improved, MM is still an incurable disease [3]. Bortezomib (BTZ) is one of the most successful chemotherapeutics for MM [4]. However, although BTZ has achieved clinical success, some patients have failed BTZ treatment due to primary or secondary drug resistance [5]. Therefore, finding effective markers for prognosis and new therapeutic targets for MM has important clinical significance. New characteristic target molecules may provide the possibility of finding new methods for the treatment and prognostic evaluation of MM.

Extracellular vesicles, including exosomes, have recently been identified as the third mediators of cellular communication [6]. Exosomes are a type of bilayer lipid membrane vesicle with a diameter of about 30 to $100 \mathrm{~nm}$. They are found in almost all body fluids, including plasma, serum, saliva, milk, cerebrospinal fluid, and urine [7], and they are particularly abundant in the microenvironment of tumors. Exosomes contain a variety of proteins and nucleic acid components, among which the RNA molecules include mRNA, miRNA, IncRNA, and circRNA [8]. Exosomes can carry these functional substances to transfer them between cells, mediate information exchange, and regulate a variety of physiological and pathological activities such as cell protein synthesis, proliferation, differentiation, and antiviral response [9].

CircRNA is non-coding RNA with a circular structure, forming a covalently closed continuous loop containing hundreds to thousands of base pairs, which is not degraded by exonuclease [10]. CircRNA is stable and widely present in the body, such as in cytoplasm, nuclei, serum exosomes, and saliva [11]. Studies have found that circRNA plays an important role in normal physiological processes and the occurrence and development of various diseases, and it can be used as a clinical diagnostic marker for various diseases [12]. The application of highthroughput sequencing technology has identified a large number of circRNAs and led to the establishment of circRNA databases such as CircBase and CircNet $[13,14]$. Previous studies have shown that serum circRNA can be used as a biomarker for many tumors [15]. The circRNA circMYC (hsa_circ_0085533) is derived from the $M Y C$ gene and contains an exon circRNA transcript located on chromosome 8. CircMYC has been reported to promote the proliferation of breast cancer cells [16] and human melanoma cells [17]. However, the expression of circulating exosomal circMYC in patients with MM and its role in prognostic evaluation remain unclear. This study focused on the expression of circMYC in the serum exosomes of patients with $\mathrm{MM}$ and its role in the evaluation of relapse and drug resistance in these patients.

\section{Materials and Methods}

\section{Human Samples}

From January 2014 to January 2019, we collected peripheral serum samples and clinical case data of 122 patients diagnosed with $\mathrm{MM}$ in our hospital. We also collected the clinical and pathological data of the patients, including age (ranging from 41 to 76 years old), gender ( 79 male and 43 female patients), disease classification, and clinical stage [Durie-Salmon staging (DSS) and International Staging System (ISS)]. The diagnosis of MM patients was based on the diagnostic criteria of the International Myeloma Working Group [18]. In addition, 54 peripheral serum samples from healthy individuals were collected as a control group. The healthy controls were included based on the following criteria: no previous history of malignant tumors, and normal liver and kidney functions. The study was approved by the Ethics Committee of The Third Xiangya Hospital, Central South University. All subjects signed the informed consent form.

\section{Exosome Isolation and Identification}

The serum was thawed on ice and then centrifuged at 2000x $\mathrm{g}$ for $30 \mathrm{~min}$ at $4{ }^{\circ} \mathrm{C}$ to remove debris. The supernatant was filtered through a $0.22-\mu \mathrm{m}$ filter. The filtered supernatant was then transferred to a $50-\mathrm{mL}$ ultrafiltration tube. The exosomes were extracted using an exosome isolation kit (EXOTC50A-1, System Biosciences, Palo Alto, CA, USA). Briefly, 0.5 times the volume of the extraction reagent was added and mixed well with the filtered supernatant, and this mixture was incubated at $4{ }^{\circ} \mathrm{C}$ overnight. After that, the samples were centrifuged at $10000 \mathrm{x} g$ for $60 \mathrm{~min}$ at $4{ }^{\circ} \mathrm{C}$. The supernatant was discarded, and the exosome pellets were resuspended in PBS. Samples of $10 \mu \mathrm{L}$ were used for transmission electron microscopy observations, and $100 \mu \mathrm{L}$ was used for RNA extraction and quantitative polymerase chain reaction (qPCR) analysis.

\section{Transmission Electron Microscopy to Observe Exosomes}

The morphologies of the exosomes were observed by transmission electron microscopy as previously described [19]. Briefly, the exosomes were fixed with $4 \%$ glutaraldehyde solution and then stained with phosphotungstic acid (2\%) for $30 \mathrm{~s}$. Morphology was observed under a transmission electron microscope at an acceleration voltage of $80 \mathrm{kV}$. 


\section{Ribonuclease R Treatment}

Ribonuclease $\mathrm{R}$ (RNase $\mathrm{R}$ ) digests almost all linear RNA molecules, but it is not easy to digest circular RNAs. RNase $R$ can be used to digest linear RNA and identify circular RNAs [20]. RNase R (10 $\mathrm{U}$; Geneseed, Guangzhou, China) was added to $2.5 \mu \mathrm{g}$ of total RNA and mixed well for $30 \mathrm{~min}$ of incubation at $37^{\circ} \mathrm{C}$. The qPCR experiments were then performed as described below.

\section{Quantitative Polymerase Chain Reaction}

The Plasma/Serum Exosome Purification and RNA Isolation Mini Kit (Cat No. 58300, Thorold, Canada) was used to extract RNA from exosomes according to the manufacturer's instructions. SYBR Premix EX Taq II (TaKaRa, Mountain View, CA, USA) was used for real-time qPCR on the ABI 7500 Real-Time PCR System (SeqGen, Inc., Torrance, CA, USA). GAPDH was used as an internal control. Three replicates were designed for each sample. The primers used were as follows: circMYC, forward: CTCACAGCCCACTGGTCCTC, reverse: TCCAGCAGAAGGTGATCCAG; GAPDH, forward: GAAAGCCTGCCGGTGACTAA, reverse: TतCCGTTCTCAGCCTTGAC. Data are presented as fold change relative to the mean of circMYC in healthy subjects.

\section{Statistical Analysis}

We used SPSS 21.0 (IBM Corp., Armonk, NY, USA) for statistical analysis. The unpaired t-test method was used to analyze the differences of the expression levels of circMYC in circulating exosomes between patients with $\mathrm{MM}$ and healthy people. The chi-square test was used for analyzing the differences between clinical features and circMYC expression. Kaplan-Meier survival curves with log rank testing were used for estimating significance in survival rates. A Cox regression model was used for univariate and multivariate analysis. The significance level was defined as $p<0.05$.

\section{Results}

\section{Clinical Characteristics of Patients with MM}

The clinical characteristics of 122 patients with MM are shown in Table 1. The total group of patients comprised 79 men and 43 women; the median age was 62 years (41-76 years). Eightyfour cases (68.9\%) were stage I or II according to the ISS, while 38 cases (31.1\%) were stage III; for DSS stages, 87 cases (71.3\%) were stage I or II, while 35 cases (28.7\%) were stage III. Regarding the type of monoclonal immunoglobulin, 71 cases (58.2\%) were of the IgG type, 32 cases (26.2\%) were IgA type, 9 cases (7.4\%) were $\lg D$ type, and 10 cases (8.2\%) were $\lg \mathrm{M}$ type. The median hemoglobin level was $7.3(4.5-12.8) \mathrm{g} / \mathrm{dL}$ and blood calcium was $2.5(1.8-4.73) \mathrm{mmol} / \mathrm{L}$.

\section{CircMYC Expression in Circulating Exosomes in Patients with MM}

In order to study the role of circulating exosomal circRNA in the survival and prognosis of patients with MM, we isolated and purified exosomes, which were confirmed by transmission electron microscopy (Figure 1A). The RNA of the exosomes was extracted. It was found that RNase $R$ treatment could not eliminate the expression of circMYC (Figure 1B). Compared with the healthy population, the expression level of circMYC in the serum exosomes of patients with MM was significantly increased (Figure 2A, $\mathrm{p}<0.001$ ). Eighty (65.6\%) patients had high circMYC levels (Table 1). CircMYC levels in relapsed/refractory MM (RRMM) patients were higher than those of smoldering MM (SMM) and newly diagnosed MM (NDMM) patients (Figure 2B, $p<0.001$ ). In addition, during follow-up, 20 patients with BTZ resistance were found to have higher circMYC expression in circulating exosomes than before resistance (Figure $2 \mathrm{C}, \mathrm{p}<0.001$ ).

We further analyzed the relationship between the expression level of exosomal circMYC and clinical characteristics of patients with MM. Based on the ROC curve (AUC: 0.924; Figure 3), the best cut-off was 1.83, which was very close to the mean (1.76) of exosomal circMYC in MM patients. Therefore, we used the mean value of circMYC expression as the cutoff value to divide the MM patients into a high circMYC group and a low circMYC group. The results showed that, compared with MM patients with low circMYC, the patients with high circMYC had higher percentages of deletion 17p ( $p=0.0370)$, $\mathrm{t}(4 ; 14)(p=0.0127)$, DSS stage III $(p=0.0314)$, and ISS stage III $(p=0.0450)$ (Table 1). The expression of circMYC in circulating exosomes was not significantly associated with gender, age, deletion 13q, $t(14 ; 16), t(14 ; 20)$, monoclonal immunoglobulin, hypercalcemia, renal insufficiency, anemia, or bone disease (Table 1). Univariate and multivariate Cox regression analysis
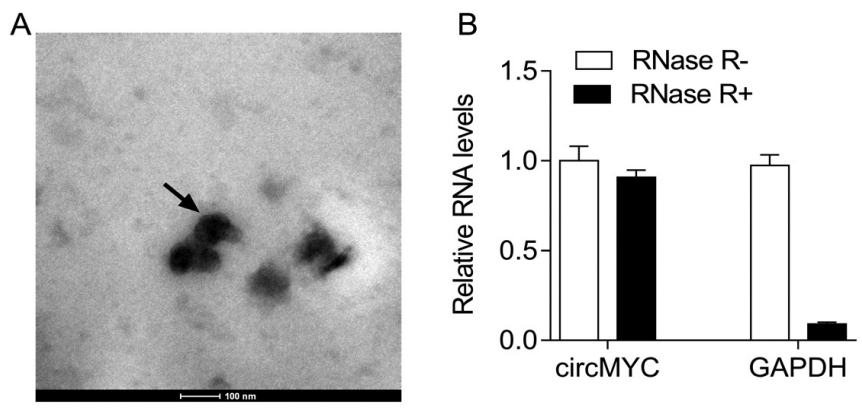

Figure 1. CircMYC expressed in exosomes from patients with multiple myeloma. (A) The morphology of circulating exosomes was observed by transmission electron microscopy. (B) qRTPCR analysis of expression of exosomal circMYC after RNase $R$ treatment. 
Table 1. Clinical association between circMYC levels and clinicopathological variables of patients with multiple myeloma.

\begin{tabular}{|c|c|c|c|}
\hline \multirow[t]{2}{*}{ Variable } & \multicolumn{2}{|l|}{ CircMYC levels } & \multirow[t]{2}{*}{ Chi-square test $p$-value } \\
\hline & Low expression $(n=42)$ & High expression $(\mathrm{n}=\mathbf{8 0})$ & \\
\hline Age & & & 0.5374 \\
\hline$\geq 60$ & 27 & 57 & \\
\hline Gender & & & 0.8428 \\
\hline Male & 28 & 51 & \\
\hline Deletion $13 q$ & & & 0.4299 \\
\hline Yes & 13 & 32 & \\
\hline No & 29 & 48 & \\
\hline Deletion $17 p$ & & & 0.0370 \\
\hline Yes & 11 & 40 & \\
\hline No & 31 & 40 & \\
\hline$t(14 ; 16)$ & & & 0.8404 \\
\hline Yes & 15 & 26 & \\
\hline No & 27 & 54 & \\
\hline$t(14 ; 20)$ & & & 0.8469 \\
\hline Yes & 18 & 32 & \\
\hline No & 24 & 48 & \\
\hline DSS & & & 0.0314 \\
\hline III & 9 & 29 & \\
\hline Monoclonal immunoglobulin & & & 0.4709 \\
\hline $\lg A$ & 14 & 18 & \\
\hline $\lg D$ & 3 & 6 & \\
\hline $\lg G$ & 22 & 49 & \\
\hline $\lg M$ & 2 & 8 & \\
\hline Hypercalcemia & & & 0.1556 \\
\hline Yes & 18 & 24 & \\
\hline No & 24 & 56 & \\
\hline Renal insufficiency & & & 0.2370 \\
\hline Yes & 13 & 17 & \\
\hline No & 29 & 63 & \\
\hline Anemia & & & 0.6597 \\
\hline Yes & 32 & 58 & \\
\hline No & 10 & 22 & \\
\hline Bone disease & & & 0.6440 \\
\hline Yes & 27 & 48 & \\
\hline No & 15 & 32 & \\
\hline
\end{tabular}


A

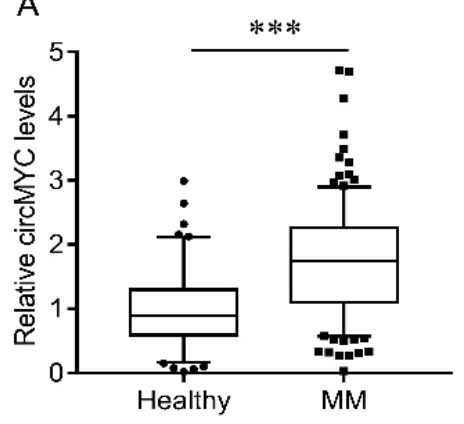

B

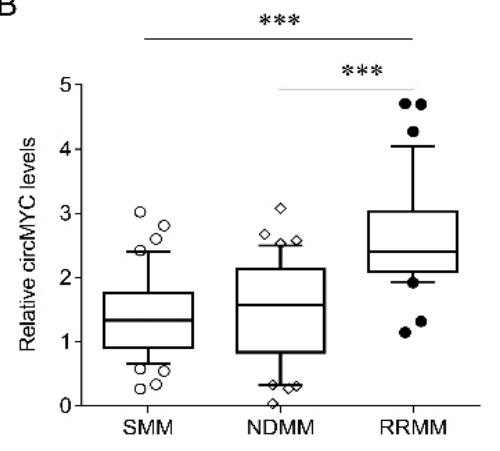

C

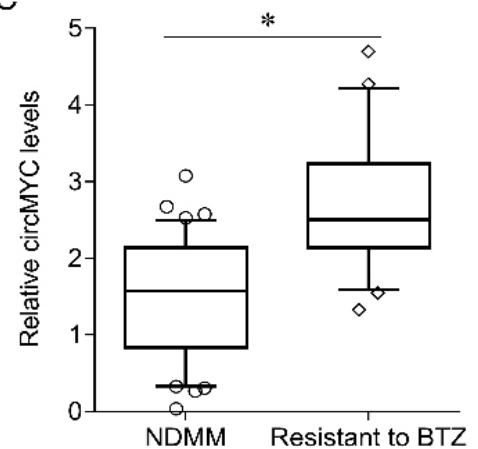

Figure 2. The expression of circMYC in multiple myeloma. (A) The expression of exosomal circMYC in patients with MM and healthy subjects. (B) The expression of exosomal circMYC in SMM, NDMM, and RRMM. (C) The expression of exosomal circMYC in bortezomibresistant MM and NDMM. MM, Multiple myeloma; NDMM, newly diagnosed MM; RRMM, relapsed/refractory MM; SMM, smoldering multiple myeloma. ${ }^{*} \mathrm{p}<0.05,{ }^{* * *} \mathrm{p}<0.001$.

found that high exosomal circMYC levels were independent predictors of poor prognosis in patients with MM (Tables 2 and 3).

\section{Association between Expression of Exosomal CircMYC and Relapse and Survival in Patients with MM}

MM patients with high exosomal circMYC had higher relapse rates (hazard ratio (HR): 4.05, 95\% confidence interval: 2.547.37, $p=0.0064$ ) and higher mortality rates (HR: 3.67, 95\% confidence interval: $1.65-5.58, p=0.0132$ ) (Table 4). Survival analysis also found that $\mathrm{MM}$ patients with high exosomal circMYC had lower overall survival $(p<0.0001)$ and progressionfree survival $(p<0.0001)$.

\section{Discussion}

There are no obvious clinical symptoms in the early stage of MM, resulting in misdiagnosis. At present, diagnosis is mainly based on bone marrow biopsy to detect the plasma as well as determining whether the patient has anemia, bone pain, hypercalcemia, or kidney dysfunction [21]. Bone marrow puncture smears and fluorescence in situ hybridization are commonly used in clinical examination, but bone marrow aspiration can cause trauma for patients [22]. In addition, during the treatment of MM, most of the patients may develop drug resistance, rendering the original treatment plan ineffective. The above tests have certain limitations in dynamically monitoring the curative effects.

\begin{tabular}{|l|l|l|}
\hline \multicolumn{3}{|l|}{ Table 2. Univariate analysis of prognostic factors of MM. } \\
\hline Variable & $\begin{array}{l}\text { Hazard ratio } \\
\mathbf{( 9 5 \%} \mathbf{~ C l )}\end{array}$ & p-value \\
\hline Deletion 17p (yes vs no) & $1.63(1.32-3.24)$ & 0.0325 \\
\hline t.(4;14) (yes vs no) & $2.20(1.59-4.03)$ & 0.0147 \\
\hline DSS (III vs I/II) & $2.84(1.46-4.63)$ & 0.0126 \\
\hline ISS (III vs I/II) & $3.04(2.09-4.71)$ & 0.0236 \\
\hline $\begin{array}{l}\text { Exosomal circMYC levels } \\
\text { (high vs low) }\end{array}$ & $2.56(1.86-3.87)$ & 0.0362 \\
\hline DSS: Durie-Salmon staging, ISS: International Staging System, Cl: confidence interval. \\
\hline
\end{tabular}

Table 3. Multivariate analysis of independent prognostic factors of MM.

\begin{tabular}{|l|l|l|}
\hline Variable & $\begin{array}{l}\text { Hazard ratio } \\
\mathbf{( 9 5 \%} \mathbf{~ C I})\end{array}$ & p-Value \\
\hline Deletion 17p (yes vs no) & $2.54(1.74-4.21)$ & 0.0346 \\
\hline t.(4;14) (yes vs no) & $3.23(1.82-5.36)$ & 0.0272 \\
\hline DSS (III vs I/II) & $3.53(2.06-5.73)$ & 0.0153 \\
\hline ISS (III vs I/II) & $4.03(2.56-6.04)$ & 0.0247 \\
\hline $\begin{array}{l}\text { Exosomal circMYC levels } \\
\text { (high vs low) }\end{array}$ & $3.64(2.24-5.38)$ & 0.0021 \\
\hline DSS: Durie-Salmon staging, ISS: International Staging System, Cl: confidence interval. \\
\hline
\end{tabular}

\begin{tabular}{|l|l|l|l|l|l|}
\hline \multicolumn{2}{|l|}{ Table 4. Association of recurrence and mortality and circMYC expression. } & HR (95\% Cl) & p-value \\
\hline Recurrence, \% & $\mathbf{1}$ year & $\mathbf{3}$ years & $\mathbf{5}$ years & & \\
\hline High circMYC & & & 49.4 & $4.05(2.54-7.37)$ & 0.0064 \\
\hline Low circMYC & 26.8 & 39.6 & 26.6 & & \\
\hline Mortality, \% & 16.3 & & & & $3.67(1.65-5.58)$ \\
\hline High circMYC & & 68.5 & 84.8 & & 0.0132 \\
\hline Low circMYC & 52.3 & 43.7 & 45.6 & & \\
\hline HR: Hazard ratio, Cl: confidence interval. & 31.3 & & & \\
\hline
\end{tabular}




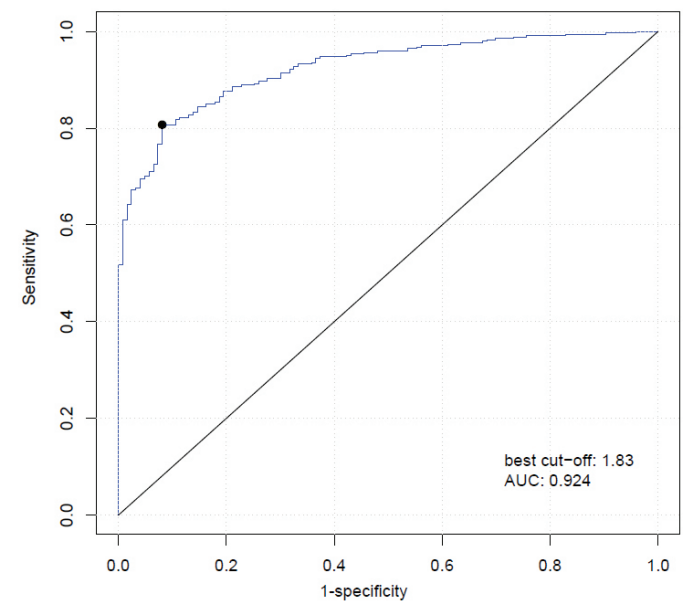

Figure 3. Based on the ROC curve (AUC: 0.924), the best cut-off was 1.83 , which was very close to the mean (1.76) of exosomal circMYC in MM patients. We thus used the mean value of circMYC expression as the cutoff value to divide the MM patients into a high circMYC group and a low circMYC group. ROC: Receiver operating characteristic, AUC: area under the curve, MM, multiple myeloma.
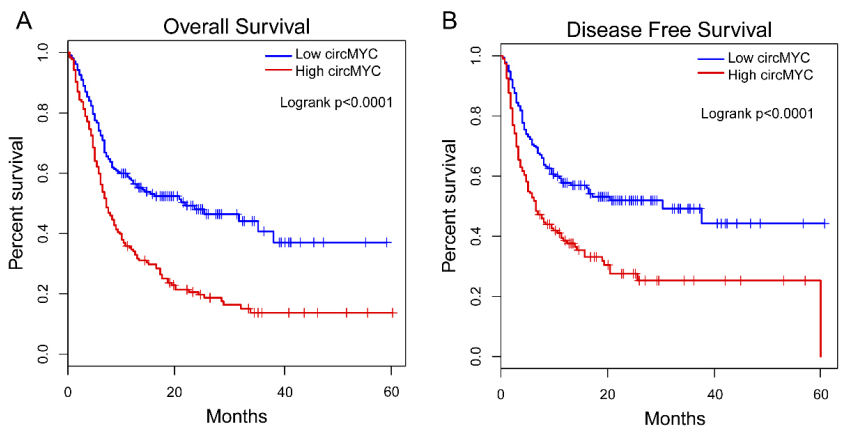

Figure 4. High exosomal circMYC is associated with worse survival rates in patients with MM. (A) The overall survival rate was evaluated by Kaplan-Meier curve. (B) The disease-free survival rate was evaluated by Kaplan-Meier curve.

However, liquid biopsy is non-invasive, dynamic, reproducible, and low-risk [23]. It can assist in early diagnosis and monitor curative effects (including post-relapse treatment), showing excellent clinical application value [24].

Because circRNAs are conserved and stable in circulation and have high time- and tissue-specific expression patterns, they have potential for clinical application as biomarkers for the diagnosis and prognosis of hematological malignancies [25]. CircRNA is closely related to the malignant transformation, curative effect, and prognosis of hematological malignancies, but the specific molecular mechanism involved in the occurrence and development of the disease remains to be further elucidated [26]. This study found that the expression of circMYC of circulating exosomes in patients with MM was significantly higher than that in healthy people and was significantly correlated with DSS and ISS staging, indicating a poor prognostic outcome. The development of MM generally ranges from monoclonal gammopathy of unknown significance (MGUS) to asymptomatic myeloma, and eventually to symptomatic myeloma. If the patient shows symptoms such as bone pain, anemia, and kidney damage, it indicates that the disease has progressed to stage III. If detected early in the MGUS and SMM stages, patients can receive timely and effective intervention. laccino et al. [7] reported that idiotype-specific binding peptides can quickly and simply identify exosomes released by MM cells, and they also found that MM-derived exosomes can be used to determine the progress of MM early compared with serum paraprotein IgG2b. Therefore, circulating exosomes may be useful tools for early detection in patients with MM.

Acquired resistance is a major obstacle to tumor chemotherapy. The communication between tumor cells and the microenvironment plays an important role in malignant tumor transformation [27]. Studies have found that exosomes can promote tumor cell proliferation, metastasis, and drug resistance in the tumor microenvironment. Exosomes contain miRNAs and circRNAs that can be transferred to recipient cells to regulate protein expression and signal pathway transduction. Recently, exosomes have been shown to be closely related to tumor development and metastasis as well as drug resistance [28]. It was reported that cisplatin can lead to increased secretion of exosomes in lung cancer cells, and the expression levels of certain miRNAs (miR-21, miR-133b) in exosomes are related to cisplatin resistance [29]. A recent study found that circular RNA Cdr1as was downregulated in serum exosomes from cisplatinresistant patients with ovarian cancer, and overexpression of Cdr1as increased the cisplatin-induced cell apoptosis in ovarian cancer cells [30]. It was also reported that circ_0000190 was downregulated in both bone marrow tissue and peripheral blood from patients with MM, and overexpression of circ_0000190 inhibited MM cell growth in vitro and in vivo through targeting the miR-767-5p/MAPK4 axis [31]. The clinical application of BTZ has improved the remission rate and survival rate of patients with MM. Bandari et al. [32] reported that the exosomes derived from myeloma cells were increased significantly by BTZ. Bone marrow mesenchymal stem cells (BMSCs) and MM cells regulate each other through exosomes, and BMSCs making MM cells evade anti-myeloma treatment is one of the factors leading to drug resistance [33]. BTZ induces MM cell death by regulating bcl-2, caspase-9, and caspase-3, while BMSC-derived exosomes inhibit the function of BTZ, leading MM cells to become resistant [33]. In this study, we found that the expression of circMYC in circulating exosomes in drug-resistant patients was significantly higher than that in non-resistant patients, suggesting that the 
expression of circMYC is associated with drug resistance in MM patients. A previous study found that circMYC was significantly associated with drug response to multiple drugs, including belinostat (an HDAC inhibitor) and cetuximab, in ways that are beyond the known mechanisms, including genomic variation and transcriptomic variation [16]. Therefore, these findings provide new ideas for the treatment of MM by targeting exosomes, which has the advantages of stability, non-toxicity, and strong delivery through blocking the communication between tumor cells and the tumor microenvironment.

\section{Study Limitations}

There are some shortcomings in our study. For example, the scale of the cohort was small and the patients' information was analyzed based on retrospective data. In addition, this study lacks functional investigation in vivo and in vitro to explore the potential role and underlying mechanisms of circMYC in MM. Cell biological experiments and prospective studies in humans should be performed in the future to confirm the conclusions of this study.

\section{Conclusion}

This study has demonstrated that circulating exosomal circMYC is upregulated in patients with MM and is associated with BTZ response and relapse, which indicates that exosome circMYC has great potential as a biomarker for the diagnosis and prognosis of MM. CircRNA is expected to be applied for the minimally invasive diagnosis and prognosis of hematological malignancies in the near future, and it may become a potential therapeutic target.

\section{Ethics}

Ethics Committee Approval: The study was approved by the Ethics Committee of The Third Xiangya Hospital, Central South University.

\section{Authorship Contributions}

Concept: Y.L., R.G.; Design: Y.L., R.G.; Data Collection or Processing: Y.L., R.G.; Analysis or Interpretation: Y.L., R.G.; Literature Search: Y.L., R.G.; Writing: Y.L., R.G.

Conflict of Interest: The authors report no conflict of interest.

Financial Disclosure: The authors declared that this study received no financial support.

\section{Acknowledgments}

This work was supported by the National Natural Science Foundation of China (no. 81573091 and no. 81802668) and the Natural Science Foundation of Hunan Province, China (no. 2018JJ3776 and No. 2017JJ3467).

\section{References}

1. Brigle $K$, Rogers B. Pathobiology and diagnosis of multiple myeloma. Semin Oncol Nurs 2017;33:225-236.

2. Rajkumar SV, Kumar S. Multiple myeloma: diagnosis and treatment. Mayo Clin Proc 2016;91:101-119.

3. Fonseca R, Abouzaid S, Bonafede M, Cai Q, Parikh K, Cosler L, Richardson P. Trends in overall survival and costs of multiple myeloma, 2000-2014. Leukemia 2017;31:1915-1921.

4. Dimopoulos MA, Goldschmidt H, Niesvizky R, Joshua D, Chng WJ, Oriol A Orlowski RZ, Ludwig $H$, Facon T, Hajek R, Weisel K, Hungria V, Minuk L, Feng S, Zahlten-Kumeli A, Kimball AS, Moreau P. Carfilzomib or bortezomib in relapsed or refractory MM (ENDEAVOR): an interim overall survival analysis of an open-label, randomised, phase 3 trial. Lancet Oncol 2017;18:13271337.

5. Fu Y, Liu X, Zhang F, Jiang S, Liu J, Luo Y. Bortezomib-inducible long noncoding RNA myocardial infarction associated transcript is an oncogene in multiple myeloma that suppresses miR-29b. Cell Death Dis 2019;10:319.

6. Faict S, Muller J, De Veirman K, De Bruyne E, Maes K, Vrancken L, Heusschen R, De Raeve H, Schots R, Vanderkerken K, Caers J, Menu E. Exosomes play a role in multiple myeloma bone disease and tumor development by targeting osteoclasts and osteoblasts. Blood Cancer J 2018;8:105.

7. Iaccino $E$, Mimmi S, Dattilo V, Marino F, Candeloro $P$, Di Loria A, Marimpietri D, Pisano A, Albano F, Vecchio E, Ceglia S, Golino G, Lupia A, Fiume G, Quinto I, Scala G. Monitoring multiple myeloma by idiotype-specific peptide binders of tumor-derived exosomes. Mol Cancer 2017;16:159.

8. Manier S, Liu CJ, Avet-Loiseau H, Park J, Shi J, Campigotto F, Salem KZ, Huynh D, Glavey SV, Rivotto B, Sacco A, Roccaro AM, Bouyssou J, Minvielle S, Moreau P, Facon T, Leleu X, Weller E, Trippa L, Ghobrial IM. Prognostic role of circulating exosomal miRNAs in multiple myeloma. Blood 2017;129:24292436.

9. Wang J, De Veirman K, Faict S, Frassanito MA, Ribatti D, Vacca A, Menu E. Multiple myeloma exosomes establish a favourable bone marrow microenvironment with enhanced angiogenesis and immunosuppression. J Pathol 2016;239:162-173.

10. Ng WL, Mohd MT, Shukla K. Functional role of circular RNAs in cancer development and progression. RNA Biol 2018;15:995-1005.

11. Bonizzato A, Gaffo $E$, Te KG, Bortoluzzi S. CircRNAs in hematopoiesis and hematological malignancies. Blood Cancer J 2016;6:e483.

12. Dahl M, Daugaard I, Andersen MS, Hansen TB, Gronbaek K, Kjems J, Kristensen LS. Enzyme-free digital counting of endogenous circular RNA molecules in B-cell malignancies. Lab Invest 2018;98:1657-1669.

13. Glazar $P$, Papavasileiou $P$, Rajewsky N. CircBase: A database for circular RNAs. RNA 2014;20:1666-1670.

14. Liu YC, Li JR, Sun CH, Andrews $E$, Chao RF, Lin FM, Weng SL, Hsu SD, Huang CC, Cheng C, Liu CC, Huang HD. CircNet: A database of circular RNAs derived from transcriptome sequencing data. Nucleic Acids Res 2016;44:D209-D215.

15. Zhao ZJ, Shen J. Circular RNA participates in the carcinogenesis and the malignant behavior of cancer. RNA Biol 2017;14:514-521.

16. Ruan H, Xiang Y, Ko J, Li S, Jing Y, Zhu X, Ye Y, Zhang Z, Mills T, Feng J, Liu CJ, Jing J, Cao J, Zhou B, Wang L, Zhou Y, Lin C, Guo AY, Chen X, Diao L, Li W, Chen Z, He X, Mills GB, Blackburn MR, Han L. Comprehensive characterization of circular RNAs in 1000 human cancer cell lines. Genome Med 2019;11:55.

17. Jin C, Dong D, Yang Z, Xia R, Tao S, Piao M. CircMYC regulates glycolysis and cell proliferation in melanoma. Cell Biochem Biophys 2020;78:77-88. 
18. Hussein MA, Vrionis FD, Allison $R$, Berenson $J$, Berven $S$, Erdem $E$, Giralt S, Jagannath S, Kyle RA, LeGrand S, Pflugmacher R, Raje N, Rajkumar SV, Randall RL, Roodman D, Siegel D, Vescio R, Zonder J, Durie BG. The role of vertebral augmentation in multiple myeloma: International Myeloma Working Group Consensus Statement. Leukemia 2008;22:1479-1484.

19. Luo $Y$, Liu F, Gui R. High expression of circulating exosomal circAKT3 is associated with higher recurrence in HCC patients undergoing surgical treatment. Surg Oncol 2020;33:276-281.

20. Cheng ZF, Deutscher MP. Purification and characterization of the Escherichia coli exoribonuclease RNase R. Comparison with RNase II. J Biol Chem 2002;277:21624-21629.

21. Landgren 0, Rajkumar SV. New developments in diagnosis, prognosis, and assessment of response in multiple myeloma. Clin Cancer Res 2016;22:54285433.

22. Rajkumar SV. Updated diagnostic criteria and staging system for multiple myeloma. Am Soc Clin Oncol Educ Book 2016;35:e418-e423.

23. Waldschmidt JM, Anand $P$, Knoechel $B$, Lohr JG. Comprehensive characterization of circulating and bone marrow-derived multiple myeloma cells at minimal residual disease. Semin Hematol 2018;55:33-37.

24. Ledergor G, Weiner A, Zada M, Wang SY, Cohen YC, Gatt ME, Snir N, Magen $H$, Koren-Michowitz M, Herzog-Tzarfati K, Keren-Shaul H, Bornstein C, Rotkopf R, Yofe I, David E, Yellapantula V, Kay S, Salai M, Ben YD, Nagler A, Shvidel L, Orr-Urtreger A, Halpern KB, Itzkovitz S, Landgren O, San-Miguel J, Paiva B, Keats JJ, Papaemmanuil E, Avivi I, Barbash Gl, Tanay A, Amit I. Single cell dissection of plasma cell heterogeneity in symptomatic and asymptomatic myeloma. Nat Med 2018;24:1867-1876.

25. Ji T, Chen $Q$, Tao S, Shi Y, Chen Y, Shen L, Wang C, Yu L. The research progress of circular RNAs in hematological malignancies. Hematology 2019;24:727731.
26. Mei M, Wang $Y$, Li Z, Zhang M. Role of circular RNA in hematological malignancies. Oncol Lett 2019;18:4385-4392.

27. Xu S, De Veirman K, De Becker A, Vanderkerken K, Van Riet I. Mesenchymal stem cells in multiple myeloma: a therapeutical tool or target? Leukemia 2018;32:1500-1514.

28. Di Marzo L, Desantis $V$, Solimando AG, Ruggieri $S$, Annese $T$, Nico $B$, Fumarulo $R$, Vacca $A$, Frassanito MA. Microenvironment drug resistance in multiple myeloma: emerging new players. Oncotarget 2016;7:60698-60711.

29. Xiao X, Yu S, Li S, Wu J, Ma R, Cao H, Zhu Y, Feng J. Exosomes: decreased sensitivity of lung cancer A549 cells to cisplatin. PLoS One 2014;9:e89534.

30. Zhao Z, Ji M, Wang $Q$, He N, Li Y. Circular RNA Cdr1as upregulates SCAl to suppress cisplatin resistance in ovarian cancer via miR-1270 suppression. Mol Ther Nucleic Acids 2019;18:24-33.

31. Feng Y, Zhang L, Wu J, Khadka B, Fang Z, Gu J, Tang B, Xiao R, Pan G, Liu J. CircRNA circ_0000190 inhibits the progression of multiple myeloma through modulating miR-767-5p/MAPK4 pathway. J Exp Clin Cancer Res 2019;38:54.

32. Bandari SK, Purushothaman A, Ramani VC, Brinkley GJ, Chandrashekar DS, Varambally S, Mobley JA, Zhang Y, Brown EE, Vlodavsky I, Sanderson RD. Chemotherapy induces secretion of exosomes loaded with heparanase that degrades extracellular matrix and impacts tumor and host cell behavior. Matrix Biol 2018;65:104-118.

33. Wang J, Hendrix A, Hernot $S$, Lemaire $M$, De Bruyne $E$, Van Valckenborgh E, Lahoutte T, De Wever O, Vanderkerken K, Menu E. Bone marrow stromal cell-derived exosomes as communicators in drug resistance in multiple myeloma cells. Blood 2014;124:555-566. 